\title{
MORPHOLOGIC STUDY OF NUTRIENT FORAMINA IN DRIED FEMURS
}

\author{
Jayaprakash $T^{1}$
}

${ }_{1}^{1}$ Assistant Professor, Department of Anatomy, Father Muller Medical College, Mangalore, Karnataka, India.

\section{ABSTRACT}

\section{BACKGROUND}

Diaphyseal fractures of femur are common cases in Orthopaedics and Traumatology Department. Vascularised bone graft is the preferred method used in bone reconstruction, as it ensures the survival of both donor and recipient bones. Position and direction of nutrient foramina in long bones of lower limbs varies from region to region, race and species.

\section{MATERIALS AND METHODS}

The descriptive study comprised of observation of Diaphyseal Nutrient Foramina (DNF) of 50 adult dried femurs. DNF was identified by their elevated margins and by the presence of a distinct groove proximal to them. Foramina equal to or larger than 24 hypodermic needle size were included. Foramen Index (FI) was calculated using Hughes formula.

\section{RESULTS}

$28(56 \%)$ bones showed single nutrient foramen, 21 (42\%) bones showed double nutrient foramina. Nutrient foramen was absent in one bone. Majority of nutrient foramina were found on the linea aspera and posterior medial surface and least on the lateral surface, whereas none were found on the anterior surface. The mean foramen index was 44.07.

\section{CONCLUSION}

The anterior and lateral surfaces of femur are safe for orthopaedic manipulations due to scarcity of nutrient foramina on these surfaces.

\section{KEY WORDS}

Diaphyseal Nutrient Foramen, Femur, Foramen Index, Bone Graft, Linea Aspera.

HOW TO CITE THIS ARTICLE: Jayaprakash T. Morphologic study of nutrient foramina in dried femurs. J. Evolution Med. Dent. Sci. 2018;7(35):3910-3912, DOI: 10.14260/jemds/2018/874

\section{BACKGROUND}

Femur is the principal load bearing bone in the thigh region of lower extremity. ${ }^{1}$ Diaphyseal nutrient artery is the chief source of blood supply to femur, which enters the bone through the diaphyseal nutrient foramen. ${ }^{2}$ The DNF in femur is directed towards the upper end (away from the growing end of the bone). ${ }^{3}$ They are found on or near the linea aspera, varying in number and site. ${ }^{1}$ It reflects the degree of bone vascularity. ${ }^{1}$ It is a well-known fact that the position of nutrient foramen is variable and may be altered during growth. ${ }^{1}$ These variations observed in the direction of nutrient foramina could be best explained with the help of vascular theory. ${ }^{4}$ Diaphyseal fractures of femur are common cases in Orthopaedics and Traumatology Department. The possible vascular injury on the precise area of nutrient foramen, nutrient canal or nutrient artery as a result of fracture, bone graft or bone resection may result in delayed union or non-union of the bone, since healing of fracture or bone graft is dependent on blood supply. ${ }^{1}$ Hence, while planning a bone graft for a patient with trauma or tumour resection, the vascularity of the left over bone in the donor site is of importance, as it influences the choice of graft to be used. $^{5}$

'Financial or Other Competing Interest': None.

Submission 11-07-2018, Peer Review 09-08-2018,

Acceptance 16-08-2018, Published 27-08-2018.

Corresponding Author:

Jayaprakash $T$,

Assistant Professor, Department of Anatomy,

Father Muller Medical College,

Mangalore, Karnataka, India.

E-mail:jp79@rediffmail.com

DOI: $10.14260 /$ jemds $/ 2018 / 874$
A good blood supply is essential for osteoblast and osteocyte survival. ${ }^{4}$ Vascularised bone graft is the preferred method used in bone reconstruction, as it ensures the survival of both donor and recipient bones. ${ }^{2}$ The present study was taken up to analyse the number, location, direction of nutrient foramina in adult dried femurs in the region of coastal Karnataka, as the information of the same could be useful for the clinicians.

\section{MATERIALS AND METHODS}

- A descriptive study was conducted on 50 adult dried femurs (23 right and 27 left). The dry bones were obtained from the MBBS students and from the osteology section of Anatomy Department, Father Muller Medical College, Mangalore.

- The damaged bones and those with gross pathological deformities were excluded from the study.

- Foramina smaller than a size 24 hypodermic needle were considered as secondary foramina and were not included.

- After side determinations, the nutrient foramina were observed in all bones. They were identified by their elevated margins and by the presence of a distinct groove proximal to them. Foramina at the ends of the bone were ignored.

- The nutrient foramina were studied with regards to the following data-

1. Number of foramina on the bone shaft.

2. Location of foramen in relation to the length of the shaft.

3. Size: Nutrient foramina smaller than the size of 24gauge hypodermic needle were considered as secondary foramina and were not included for the 
study. Foramina equal to or larger than this were considered as dominant foramina.

4. Direction and Obliquity: A fine stiff wire was used to confirm the direction and obliquity of the foramen.

Foramen Index (FI) was calculated using Hughes formula. ${ }^{6}$ $\mathrm{FI}=(\mathrm{DNF} / \mathrm{TL}) \times 100$

Where DNF: The distance between the nutrient foramen and proximal end of the bone and TL: Total Bone Length.

All measurements were done using osteometric board.

The statistical data analysis was carried out using SPSS 17 (Statistical Package for Social Sciences).

\section{RESULTS}

In the present study, 70 nutrient foramina were observed in the 50 dried femurs. $30(42.85 \%)$ nutrient foramina were observed on right side and 40 (57.14\%) were observed on left. In our study, 28 (56\%) femurs had single nutrient foramen and $21(42 \%)$ femurs had double nutrient foramina. In one femur, the nutrient foramen was not found. All the DNFs observed were directed towards the proximal end (Table 1 and Fig. 1).

The DNFs observed in vertical zones of femur include 28 on Linea aspera (LA), 24 on Medial lip of Linea aspera (MLA), 4 on Lateral lip of Linea aspera (LLA), 6 on Posterior Medial Surface (PMS), 1 on Posterior Lateral Surface (PLS) and 7 on Posterior Popliteal Surface (PPS). Distribution in horizontal zones include 57 in the middle $1 / 3^{\text {rd }}$ of the femur and 13 in upper $1 / 3^{\text {rd }}$ with no foramina detected in the distal third of the femur. The most common site of nutrient foramen was on linea aspera, least on lateral surface and none on the anterior surface. The DNFs on the upper $2 / 3^{\text {rd }}$ of linea aspera with its medial and lateral lips accounts to majority compared to other surfaces (Table 2 and Fig. 2).

The mean Foramen Index (FI) of all the studied DNFs was $44.07 \pm 11$. The mean FI of DNFs on the left femur $(45.12 \pm 11.61)$ was higher than that on the right femur $(42.77 \pm 10.25)$.

\begin{tabular}{|c|c|c|c|c|}
\hline Side & Single DNF & No DNF & Double DNF & Total \\
\hline Right & 14 & 01 & 08 & 23 \\
\hline Left & 14 & - & 13 & 27 \\
\hline Total & $\mathbf{2 8}$ & $\mathbf{0 1}$ & $\mathbf{2 1}$ & $\mathbf{5 0}$ \\
\hline \multicolumn{5}{|c|}{ Table 1. Distribution of DNFs in Femur } \\
\hline
\end{tabular}

Total no. of DNFs observed; Right: 30, Left: 40, Total: 70

\begin{tabular}{|c|c|c|c|c|c|c|c|c|}
\hline \multirow{2}{*}{ Different Zones } & LA & MLA & LLA & PMS & PLS & PPS & $\begin{array}{c}\text { Nutrient } \\
\text { Foramen }\end{array}$ \\
\cline { 3 - 9 } & $\begin{array}{c}\text { Upper } \\
1 / 3\end{array}$ & 4 & 1 & 4 & 4 & 0 & 0 & 13 \\
\hline $\begin{array}{c}\text { Horizontal } \\
\text { Zones }\end{array}$ & $\begin{array}{c}\text { Middle } \\
1 / 3\end{array}$ & 24 & 23 & 0 & 2 & 1 & 7 & 57 \\
\cline { 2 - 8 } & $\begin{array}{c}\text { Lower } \\
1 / 3\end{array}$ & 0 & 0 & 0 & 0 & 0 & 0 & 0 \\
\hline $\begin{array}{c}\text { Total Number of } \\
\text { Foramen }\end{array}$ & 28 & 24 & 4 & 6 & 1 & 7 & 70 \\
\hline $\begin{array}{c}\text { Table 2. Distribution of Nutrient Foramen on Femoral } \\
\text { Diaphysis in Vertical and Horizontal Zones }\end{array}$ \\
\hline
\end{tabular}

\begin{tabular}{|c|c|c|c|c|c|c|}
\hline $\begin{array}{c}\text { Studies } \\
\text { By }\end{array}$ & Region & $\begin{array}{c}\text { Sample } \\
\text { Size }\end{array}$ & $\begin{array}{c}\text { One Per } \\
\text { Bone \% }\end{array}$ & $\begin{array}{c}\text { Two Per } \\
\text { Bone \% }\end{array}$ & $\begin{array}{c}\text { Not } \\
\text { Found\% } \%\end{array}$ & $\begin{array}{c}\text { Nutrient } \\
\text { Foramen }\end{array}$ \\
\hline $\begin{array}{c}\text { Present } \\
\text { study }\end{array}$ & $\begin{array}{c}\text { South } \\
\text { India }\end{array}$ & 50 & 40 & 60 & 1 & 70 \\
\hline $\begin{array}{c}\text { Gopala } \\
\text { Krishna1 }^{1}\end{array}$ & $\begin{array}{c}\text { South } \\
\text { India }\end{array}$ & 126 & 59.49 & 40.51 & 0 & 158 \\
\hline $\begin{array}{c}\text { Murali- } \\
\text { manju }^{7}\end{array}$ & $\begin{array}{c}\text { South } \\
\text { India }\end{array}$ & 86 & 47.7 & 44.2 & 4.6 & 136 \\
\hline $\begin{array}{c}\text { Raj } \\
\text { Kumar }\end{array}$ & $\begin{array}{c}\text { North } \\
\text { India }\end{array}$ & 101 & 32.0 & 68.0 & 2 & 150 \\
\hline
\end{tabular}

Table 3. Number of Nutrient Foramina per Bone

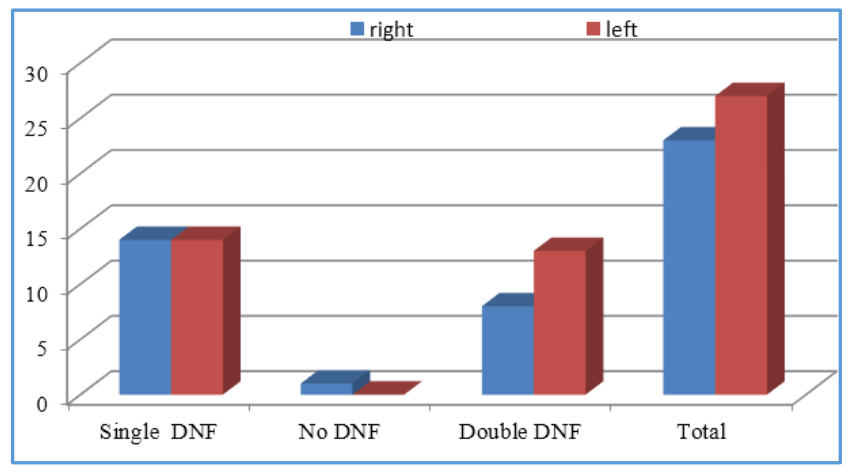

Figure 1. Distribution of DNFs in Femur



Figure 2. Distribution of Nutrient Foramen on Femoral Diaphysis in Vertical and Horizontal Zones

\section{DISCUSSION}

The number and location of the nutrient foramina are important, as the knowledge of this could be utilised by orthopaedicians during surgeries, especially for short defects. One must consider the number and location of nutrient foramina for vascularised bone graft. So this study was taken up. Of the 50 dried femurs studied (23 right, 27 left), 70 nutrient foramina were observed.

In the present study, 21 (42\%) bones showed double nutrient foramina. The present results correlate with the studies done by Gopala Krishna ${ }^{1}$ and Muralimanju. ${ }^{7}$ The blood supply to the sites of muscle attachment is directly reinforced by the nutrient arteries. The localisation of nutrient foramina in the upper $2 / 3^{\text {rd }}$ corresponds to the segment of bone with more muscle attachments sustaining more stress. On comparison we can infer that the variation in the occurrence of DNF varies not only between different populations of the world, but also between the different regions of India (Table 3 ).

The factors such as genetic constitution and food habits could be related to the difference in the occurrence of DNF in different populations, as these factors have been shown to determine the number and site of DNF. ${ }^{9}$ Absence of nutrient foramina was observed in one bone. This is in concordance 
with the previous studies. ${ }^{7}$ However, in the absence of DNF, the shaft of the femur receives irrigation from the periosteal vessels. ${ }^{2}$

In the present study, all the nutrient foramina were directed towards the proximal end of the femora (Away from the growing end). One end of the bone growing faster than the other contributes to the direction of nutrient foramen. ${ }^{7}$

Based on the size of the defect to be covered, either long or short vascularised bone graft may be indicated. The anterior and lateral surfaces are safe for orthopaedic manipulations due to scarcity of nutrient foramina. In transplant techniques, diaphyseal vascularity should be maintained by preserving the DNF. ${ }^{2}$ Also, if endosteal vascularisation is to be included, the segment of donor bone to be grafted must contain DNF. 2

Carroll et al ${ }^{10}$ opined that any damage to the precise area of nutrient foramen or nutrient canal or nutrient artery by traumatic or iatrogenic reasons may result in delayed union or non-union as healing process is dependent on blood supply. Hence, the knowledge on incidence, position and distribution of the nutrient foramina is important for a clinician. The present study provides information about the size, direction and distribution of diaphyseal nutrient foramina in adult dried femurs of coastal Karnataka region.

\section{Limitations of the Study}

The present study was done on the small sample size. Moreover, the age and gender differences were not considered in this study. The gender differences might alter the position and morphology of nutrient foramina in males and females. Moreover, the nutrient foramina of the long bones might be altered during growth; hence, the sample of long bones confined to a specific age group would be better. Hence, further studies carried on with a larger sample size would provide larger dataset which will outline the relationship and significance of number, size and location of nutrient foramen with bone metabolic activity level, static and dynamic stresses on different zones or segment of bone.

\section{CONCLUSION}

The current study concludes that the occurrence of single DNF is greater than double DNF when considered in western coastal region of south India. Majority of nutrient foramina were seen in the middle $1 / 3^{\text {rd }}$ of posterior surface of femur.
The anterior and lateral surfaces are ideal locations for orthopaedic interventions due to scarcity of nutrient foramina on these surfaces. Thus, the knowledge on localisation of DNF helps the clinicians involved in surgical procedures. This knowledge is also useful for the orthopaedicians in evaluation of stress fractures.

\section{REFERENCES}

[1] Krishna GK, Rathna BS. The study on the incidence and direction of nutrient foramina in the diaphysis of femur bone of south Indian origin and their clinical importance. International Journal of Basic and Life Sciences 2014;2(2):11-9.

[2] Oyedun OS. Morphometric study of diaphyseal nutrient foramen in dried Nigerian femurs: implications for microvascular bone graft. Advances in Life Science and Technology 2014;23:91-6.

[3] Mysorekar VR, Nandedkar AN. Diaphysial nutrient foramina in human phalanges. J Anat 1979;128(Pt 2):315-22.

[4] Longia GS, Ajmani ML, Saxena SK, et al. Study of diaphyseal nutrient foramina in human long bones. Acta Anat (Basel) 1980;107(4):399-406.

[5] Menck J, Dobler A, Dohler JR. Vaskcularisation des humerus. Langenbecks Archiv fur Chirurgie 1997;382(3):123- 7.

[6] Hughes $\mathrm{H}$. The factors determining the direction of the canal for the nutrient artery in the long bones of mammals and birds. Acta Anat (Basel) 1952;15(3):261-80.

[7] Muralimanju BV, Prashanth KU, Prabhu LV, et al. Morphological and topographical anatomy of nutrient foramina in the lower limb long bones and its clinical importance. Australas Med Journal 2011;4(10):530-7.

[8] Kumar R, Mandloi RS, Singh AK, et al. Analytical and morphometric study of nutrient foramina of femur in Rohilkhand region. Innovative Journal of Medical and Health Science 2013;3:52-4.

[9] Srivastava R, Saini V, Rai RK, et al. A Study of sexual dimorphism in the femur among North Indians. Journal of Forensic Sciences 2012;57(1):19-23.

[10] Carroll SE. A study of the nutrient foramina of humeral diaphysis. The Journal of Bone and Joint Surgery 1963;45-B:176-81. 